\title{
INTERNATIONAL CONFERENCES
}

ТосиюКи СИМОСАТО (ПедагоГический ин-т Дзёэцу)

\section{История дискурсов в Японии \\ по истории общественной мысли дореволюционной России:}

Исторический обзор

Рассмотрение истории дискурсов японской интеллигенции об идейном наследии дореволюционной России имеет свою задачу; выяснить влияние русской мысли на образование и развитие самосознания мыслящих людей Японии и в то же время многосторонний смысл самих русских идей, которые, на мой взгляд, могут быть выражена через историческую полифонию всех вместе взятых течений общественной мысли.

1. Творчество русских мыслителей на первом этапе модернизации Японии.

Хорошо известно то, что в политической сфере форма действия народников второй половины 19-го века была принята примером у оппозиционного движения Японии в начале 20-го века, а в области мысли в читающей публике пользовалась популярностью прежде всего нравственная мысль Льва Толстого. Кроме нее стала известной публике Японии историческая философия Льва Ильича Мечникова, который в 70-х годах был в Японии и преподавал в Токийском университете иностранных языков. В 1910 г. его большое сочинение «Цивилизация и великие исторические реки» (1898) было переведено на японский язык.

2. Русская идея как альтернативное мышление в Японии периода колониализма и империализма.

Захватническая война Японии привела к обострению противоречий между Японией и Россией, а потом СССР. Что касается общественной мысли России, то она была воспринята японской интеллигенцией как теоретический источник, который мог бы дать ей аргументы для критики существующего режима страны. Здесь мы отмечаем два основных идеологических направления; анархизм и большевизм. В качестве представительного учения об анархизме пользовалось популярностью идейное наследие Петра Кропоткина. В исследовании проф. Сакона говорится, что в книге Т. Нисикавы «Состояние партии нигилизма в России», которая издана в 1881Г, впервые была сообщена японским читателям идея Кропоткина вместе с мыслями А. Бакунина и К. Маркса. С этого времени, особенно в четении 20-х годов, опубликовались многочисленные переводы произведений кропоткина. Например, его «Взаимная помощь» (1907) была переведена на японский язык известным анархистомпублицистом Сакаэ Осуги именно в 1917Г., а через 8 лет выпущено уже 32-е издание зтого перевода.

3. Общественная мысль России в период демократизации послевоенной Японии. 


\section{INTERNATIONAL CONFERENCES}

Нельзя не сказать о большом значении марксизма-ленинизма в демократических и социалистических движениях Японии под оккупацией США. Кроме марксизма, нам надо отметить творческое наследство Н. Г. Чернышевского, которое пользовалось вниманием мыслящих читателей Японии. Оно было воспринято у них как предшественник революционной мысли России. Его сочинение «Антропологический принцип в Философии» (1860) было переведено на японский язык в 1955г. врачом-мыслителем М.Мацуда. Можно сказать, что попытки японской интеллигенции понять внутренний процесс развития самосознания России имеют два направления: социалистическое и философское. К первому относятся следующие книги: «Введение к истории общественного движения в России» (1948) X. Морикавы и «Заря революционного движения в России» (1960) известного социалиста Кансона Арахаты. Книга Морикавы была напечатана на основе его лекций в научном собрании группы «Беседа по культуре» (Бунка-конва-кай). Морикава объяснял свою цель: дать читателям предварительное знание для чтения «Истории Всесоюзной Коммунистичекой партии (б), Краткого курса». Ко второму принадлежат следуюшие сочинения: «История русской философии» Е. Л. Радлова, которое было переведено на японский язык в 1950 г., труд о «Бердяеве»(1961) С. Тагути, его же «История русской религиозной мысли»(1974) и «Нстория политической мысли России Нового времени»(1961) К. Кацуты. Эти два направления интерпретаций русской мысли связываются с общим духовным обстоятельством в Японии, т. е. с противоречием между социалистическими идеями и экзистенциализмом. Тем не менее, можно затетить, что оба они имели общее стремление к тому, чтобы найти в русской идеи скорее всечеловеческую универсальность, чем ее своеобразность. Считаем, что в развитии самосознания японской интеллигенции оригинальное место занимает первое сочинение замечательного историка С. Ториямы «Россия и Европа», которое было издано в 1949 г. В введении своей книги он вспоминает о своем детстве. Он вырос на острове Хоккайдо, а потом переселился на Тайвань, который тогда был под властью японии. В качестве историка он усматривает аналогию между своим «детским» сознанием своеобразности Хоккайдо в отличие от «внутренности страны» и тем сознанием Николая Яковлевича Дани левского, который утверждал, что Россия не принадлежит Европе. Имея в виду время войны, он пишет: «может быть, не позволено кончить с делами простой насмешкой над протестом этого мальчика и утверждением русского националиста, так как мы знаем, что в Японии до 15 августа (1945 г.) утверждалась своеобразность своей страны с большей наивностью, чем в России, и что этот протест Японии против Западной культуры являлся более детским, чем протест этого мальчика». (C. 3)

4. Подъем интереса к народничеству в Японии второй половины $70-\mathrm{x}$ гг. и первой половины 80-х гг.

В области исследования идейного наследия России, преимущественно народников, памятником стали две книги проф. Х. Вады: «николай Рассель: 


\section{INTERNATIONAL CONFERENCES}

зарубежный народник» (1973) и «Маркс-Энгельс и революционная Россия» (1975). Как участник антивоенного движения против Вьетнамской войы он усматривал аналогию между своей деятельностью и антивоенной работой Н. Расселя среди военнопленных во время японско-русской войны. Проф. Вада утверждает, что необходимо не рассмотреть историю взаимоотношений обеих стран с точки зрения центра, как бы Москвы и Токио, а образно говоря, знать историю сношения русских и японцев по собственному опыту. («Рассель», Т. 1. С.4). Что касается его труда «Маркс-Энгельс и революционная Россия», то его можно понять в контексте критики сталинизма, критики ленинского марксизма в Японии того времени. В противовес идейному течению так называемой «школы гражданского общества», которое на основе интерпретации оригинальных текстов раннего Маркса критикует ленинский марксизм, проф. Вада посредством рассмотрения идейного взаимоотношения между Марксом-Энгельсом и народниками России утверждал оригинальность своей работы как «последовательную опыту понимания взглядов Маркса и Энгельса на Россию и критического рассмотрения русского марксизма с позиции народничества». Но после окончания Вьетнамской войны ряд событий конца 70-х и начала 80-х гг. (гражданская война Кампучии, Китайско-вьетнамская война и Афганская война) приводит к распаду «осознания общих задач» среди интересующихся русской мыслью. Например, редактор сборника статей «Жизнь и мысль Н. Г. Чернышевского (1981), Ю. Канэко объясняет цель редакционной дискуссии так: «она не намерена искать совершенное согласие взглядов» (С.1), указав в качестве примера разнообразия тематики исследовании по русской общественной мысли на следующую литературу: Ё. Имай, «Кооперация и социализм», 1988; И. Нсикава , «Герцен и Чернышевский», 1988; Х. Мацубара, «История русской интеллигенции: Разумник и вопрос Карамазовых», 1989.

5. Современное состояние изучения русской общественной мысли в Японии.

В начале 90-х Гг. переведены на японский язык две книги: сборники «Вехи» и «Из глубины» на фоне обстоятельств «перестройки». Одним из редакторов этих работ является проф. М. Наганава, который, исходя из изучения А. Н. Герцена, долгое время занимается исследованием истории церкви православия в Японии, и у которого есть сочинение «Люди Николаевского собора» (1989). Другим из редакторов этих переводов является проф. М. Микосиба, который известен как автор японского перевода «Избранных сочинений В. Соловьева». Проф. Наганава в комментарии к сборнику «Вехи» пишет так: «в сборниках «Вехи» и «Из Глубины» включено много прозрений, предвидящих состояние не только Советской России под «перестройкой», но и нашего мира «либерализма». Страдает болезнью не один социализм, а Советская Россия». Очевидно, что он старается найти в русской мысли идею для преодоления модернизма, в том числе и марксизма. Нам надо обратить внимание на замечательное сочинение проф. Ё. Накамуры «В поисках Святой Руси: утопическое предание староверов» (1990), который является одним из ученых, изучающих 


\section{INTERNATIONAL CONFERENCES}

самостоятельно от всякой конъюнктуры и положительно русскую культуру. Он пишет в сборнике статей, посвященном самому себе в 1995 г., так: «для меня большая радость то, что в нем сфера предмета изучения очень широкая и точки зрения и стили авторов разнообразные. Это означает признаки мужества в уме и богатства в духе». Вместе с разнообразием интереса японской интеллигенции к общественной мысли России нужно отметить усовершенствование в области методологии. Вооше говоря, чертами ученых молодого поколения является, во-первых, удаленность от политики и от осознания общих задач, во-вторых, постановка вопроса универсального с позиции самостоятельной индивидуальности, в-третьих, позитивное исследование «текстов» или «дискурсов» творчества мыслителей. В заключении я хотел бы объяснить ту ситуацию, что к концу 90-х Гг. у нас появилось молодое поколение ученых, которые работали аспирантами-стажерами в СССР и в России на основе нового договора 1988 г. по культурному обмену. Но, к сожалению, с 1992-го г. высылка студентов-аспирантов в Россию задержана по решению МНП Японии. Для укрепления взимопонимания между народами стран, составляющих «Восточную Азию», необходимо укрепление культурной инфраструктуры.

Статья представляет собой исправленный вариант доклада, прочитанного на секции «Закономерности межкультурных связей» на Международной конференции, посвященной 100-летию со дня рождения академика М. П. Алексеева, 17 сентября 1996 г. в Пушкинском доме (г. Санкт-Петербург). Отдельные положения доклада были подробнее развиты во время дискуссии за круглым столом на тему:«Образ России», в которой участвовали следующие ученые: В. Е.Багно (доктор филологических наук), Ю. Д. Левин (доктор филологических наук), Н. Н. Скатов (директор Пушкинского дома), С. А.Фомичев (Зав. Отделом пушкиноведения Института русской литературы РАН), В. В.Жирмунская-Аствацатурова, А. Я. Звигильский(Франция), ДЖ. Майклсон (США), Ш. Окабэ (Япония) и др.

Митико ИКУТА (Осакский институт нностранныХ языков)

\section{Переворот в восприятии образа России в Японии}

(от страны «красных варваров» к стране милостивой государыни Екатерины)

Тема данной работы - переворот в восприятии образа России в Японии. Моя цель - объяснить, почему в конце 18 века Россия в представлении японцев превратилась из «страны красных варваров» в страну милостивой государыни Екатерины. 